Jurnal Health Sains: p-ISSN: 2723-4339 e-ISSN: 2548-1398

Vol. 2, No. 6, Juni 2021

\title{
IDENTIFIKASI SENYAWA TERPENOID DAN STEROID PADA BEBERAPA TANAMAN MENGGUNAKAN PELARUT N-HEKSAN
}

\author{
Angel Novia Fransiska, Diba Masyrofah, Hermin Marlian, Irene Virda Sakina dan Putri \\ Setya Tyasna \\ Universitas Singaperbangsa Karawang, Jawa Barat, Indonesia \\ Email:1910631210056@student.unsika.ac.id, \\ 1910631210085@student.unsika.ac.id, \\ 1910631210065@student.unsika.ac.id, \\ 1910631210009@student.unsika.ac.id dan
} 191063121008@student.unsika.ac.id

\begin{tabular}{l}
\hline ARTIKEL INFO \\
\hline Tanggal diterima: 5 Juni 2021 \\
Tanggal revisi: 15 Juni 2021 \\
Tanggal yang disetujui: 25 Juni \\
2021
\end{tabular}

Keywords: identification of compounds; terpenoids; steroids; $n$-hexane solvent. \begin{abstract}
Hexane is a hydrocarbon compound of alkanes with the chemical formula C6H14. The prefix hex refers to the six carbon atoms found in the hexane and the suffix ana is derived from the word alkane which refers to the single bond connecting the carbon atoms. Identification of terpenoid compounds and steroids has been identified in several plants, namely Red Shoots (Syzygium myrtifolium Walp.), Salam (Syzygium polyanthum), bilaran Tapah (Argyreia nervosa (Burm. F.), Blind (Excoecaria agallocha L.), as well as on the lotion preparations Citrus hystrix DC. This study was conducted to determine the content of terpenoid compounds and steroids found in some parts of plants using $n$-hexane solvents. Research used is qualitative research with Lieberman Burchard method. Review this article using a method of literature study by searching sources and literature with data form in the form of national journals to international journals about the last 10 years (2012-2021). Identification is carried out on extracts, fractions, isolates and lotion preparations using liquid vacuum chromatography, column chromatography, thin-layer chromatography, and LiebermanBurchard reagents. The results showed that all of the samples were positive for terpenoid compounds and steroids using $n$ hexane solvents.
\end{abstract}

\section{ABSTRAK}

Heksana adalah senyawa hidrokarbon alkana dengan rumus kimia $\mathrm{C}_{6} \mathrm{H}_{14}$. Awalan heks menunjukan pada enam karbon atom yang terdapat pada heksana dan akhiran ana berasal dari kata alkana yang menunjuk pada ikatan tunggal yang menghubungkan atom-atom karbon tersebut. Telah dilakukan identifikasi senyawa terpenoid dan steroid pada beberapa tanaman, yaitu Tanaman Pucuk Merah (Syzygium myrtifolium Walp.), Salam (Syzygium polyanthum), Bilaran Tapah (Argyreia nervosa (Burm. F.), Buta-buta (Excoecaria agallocha L.), serta pada sediaan losion Daun Jeruk Purut (Citrus hystrix DC). Penelitian ini dilakukan untukmengetahui kandungan senyawa terpenoid dan steroid yang terdapat pada beberapa bagian tanaman menggunakan pelarut

Fransiska, Angel Novia (2021) Identifikasi Senyawa Terpenoid dan Steroid pada Beberapa Tanaman Menggunakan Pelarut N-Heksan. Jurnal Health Sains 2(6). https://doi.org/10.46799/jhs.v2i6.180 2723-6927 Ridwan Institute 
n-heksan. Penelitian yang digunakan adalah penelitian kualitatif dengan metode Lieberman Burchard. Review artikel ini menggunakan metode berupa studi pustaka dengan mencari sumber dan literatur dengan bentuk data berupa jurnal nasional sampai jurnal internasional sekitar 10 tahun terakhir (20122021). Identifikasi dilakukan terhadap ekstrak, fraksi, isolat dan sediaan losion menggunakan kromatografi vakum cair, kromatografi kolom, kromatografi lapis tipis, dan pereaksi

Kata Kunci: identifikasi senyawa; terpenoid; steroid; pelarut n-heksan.
Lieberman-Burchard. Hasil penelitian menunjukkan bahwa semua sampel tersebut positif mengandung senyawa terpenoid dan steroid menggunakan pelarut n-heksan.

\section{Pendahuluan}

Heksana adalah senyawa hidrokarbon alkana dengan rumus kimia $\mathrm{C}_{6} \mathrm{H}_{14}$. Awalan heks menunjukan pada enam karbon atom yang terdapat pada heksana dan akhiran ana berasal dari kata alkana yang menunjuk pada ikatan tunggal yang menghubungkan atomatom karbon tersebut (Anggraeni, 2016). Pelarut n-heksana adalah pelarut non-polar yang bersifat stabil dan mudah menguap, selektif melarutkan dan mengekstrak pewangi dalam jumlah besar (Irawan, 2010). Tanaman Pucuk Merah (Syzygium myrtifolium Walp.) merupakan spesies dari famili Myrtaceae. Syzygium Myrtifolium Walp merupakan tanaman semak cemara golongan angiospermae, memiliki biji dikotil dan tanaman tropis atau subtropis, dengan ketinggian berkisar antara 2 sampai 20 meter. Tanaman ini memiliki dua warna daun yaitu merah dan hijau dengan permukaan daunnya halus dan mengkilap. Tanaman ini memiliki beberapa nama lokal yaitu Pokok Kelat Paya (Malaysia), Ubah Laut (Malaysia Timur), Chinese Red-Wood (Chinese), Wild Cinnamon, Red-lip, Australian Brush Cherry dan Kelat Oil. Telah diisolasi senyawa asam betulinat dan Dimethyl cardamonin (DMC) pada daun hijau Syzygium myrtifolium Walp serta telah diketahui golongan senyawa metabolit sekunder yang terkandung dalam daun merah Syzygium myrtifolium Walp adalah golongan alkaloid, triterpenoid, steroid, saponin, fenolik dan flavonoid. tanaman ini juga bersifat sitotoksik dan memiliki aktivitas antibakteri.

Tumbuhan Salam (Syzygium polyanthum) merupakan salah satu tumbuhan yang tumbuh subur di Indonesia. Daun Salam ini mengandung flavonoid, alkaloid, fenolik, steroid, terpenoid, dan saponin (Habibi et al., 2018). Kandungan senyawa dalam daun tersebut dimungkinkan juga dimiliki pada bagian korteks batangnya. Tumbuhan Salam banyak digunakan sebagai rempah pengharum makanan dan dikenal pula sebagai tumbuhan berkhasiat obat oleh masyarakat Indonesia. Daun Salam banyak digunakan oleh masyarakat untuk mengobati asam urat, kolesterol tinggi, tekanan darah tinggi (hipertensi), kencing manis (diabetes mellitus), sakit maag (gastritis), dan diare. Salam tumbuh subur di pulau Jawa dataran rendah sampai ketinggian 1400 meter di atas permukaan laut. Salam mempunyai pohon yang besar dan tingginya dapat mencapai 2025 meter. Dalam penelitian ini dilakukan skrining fitokimia ekstrak n-heksan korteks batang Salam. Hasil uji fitokimia menunjukkan bahwa ekstrak n-heksan korteks batang Salam mengandung senyawa metabolit sekunder golongan steroid, terpenoid, dan triterpenoid, tetapi tidak mengandung kelompok senyawa flavonoid, alkaloid, fenolat, tannin, dan saponin. Senyawa metabolit sekunder yang ada dalam ekstrak n-heksan korteks batang Salam ini dimungkinkan berfungsi sebagai antimikroba. 
Daun bilaran tapah (Argyreia nervosa (Burm. F.). Tumbuhan ini secara empiris digunakan oleh masyarakat Kalimantan selatan sebagai obat batuk dan demam (antipiretik). Genus Argyreia memiliki aktivitas sebagai antiinflamasi, imunomodulator, antitumor, antidiabetes, hipoglikemia, spasmolitik, dan antimikroba. Hasil skrining fitokimia terhadap ekstrak etanol daun A. nervosa menunjukkan esktrak tersebut mengandung alkaloid, flavonoid, fenol, tanin, saponin, terpenoid, dan antrakuinon melaporkan bahwa ekstrak etanol daun A. nervosa berpotensi sebagai antimalaria. Berdasarkan informasi di atas, maka perlu dilakukan eksplorasi senyawa dari fraksi n-heksana dari ekstrak etanol daun A. nervosa. Penelitian ini dimaksudkan untuk mengisolasi salah satu senyawa dari fraksi nheksana menggunakan metode kromatografi cair vakum dan dilanjutkan dengan metode kromatografi kolom gravitasi.

Excoecaria agallocha L., famili Euphorbiaceae, tersebar luas di daerah tropis Afrika, Asia dan daerah pesisir laut dan tepi hutan bakau. Tumbuhan dari genus Excoecaria mencakup 40 spesies, tersebar di kawasan bakau tropis di Afrika, Asia dan barat laut Australia. Spesies yang paling banyak dilaporkan adalah mangrove Excoecaria agallocha Linn. Australia Seperti yang kita ketahui bersama, tumbuhan ini memiliki peranan penting dalam bidang ekonomi, ekologi serta berperan dalam obat- obatan. Getah dari tanaman ini sudah digunakan sebagai obat pencahar dan aborsi, serta dalam pengobatan maag, rematik, lepra dan kelumpuhan, sedangkan daun dari pohon ini telah digunakan sebagai racun ikan di beberapa negara seperti India, KaledoniaBaru dan Malaysia, adapun kulit dan kayunya digunakan sebagai obat untuk perut kembung di Thailand. Beberapa penelitian pada pohon kayu Buta-buta didapatkan kandungan metabolit sekunder antara lain alkaloid, flavonoid, steroid, saponin dan terpenoid.
Sejumlah senyawa terpenoid telah diisolasi dari bagian kulit batang, daun dan getahnya, sedangkan sejumlah senyawa diterpenoid, triterpenoid derivatif juga telah diisolasi dari beberapa bagian dari pohon E. agallocha yang telah terbukti bioaktif terhadap seranggadan parasit. Terpenoid dan steroid pada bagian akar tanaman ini juga telah diketahui melalui uji pendahuluan fitokimia.

Jeruk purut termasuk dalam suku Rutaceae yang berasal dari Asia Tenggara dan banyak ditanam di beberapa negaratermasuk Indonesia. Tanaman ini berpotensi sebagai penghasil minyak atsiri khususnya pada bagian kulit buah dan daunnya. Daun jeruk purut mengandung sabinena dan limonena yang berguna untuk kosmetik, aromaterapi, pencuci rambut, antelmintik, obat sakit kepala, nyeri lambung dan pengusir serangga alami, daun jeruk purut mengandung tanin $1,8 \%$, steroid, triterpenoid dan kandungan utama daun jeruk purut adalahminyak atsiri yang bisa mencapai kadarantara 2-3,5\%. Minyak atsiri daun jeruk purut mengandung senyawa kimia seperti eugenol, linalool, sitronelal dan geraniol dikenal sebagai zat penolak serangga sehingga zat-zat tersebut juga berfungsi sebagai pengusir nyamuk dengan cara menyamarkan zat atraktan (penarik).

\section{Metode Penelitian}

Review artikel ini menggunakan metode berupa studi pustaka dengan mencari sumber dan literatur dengan bentuk data berupa jurnal nasional sampai jurnal internasional sekitar 10 tahun terakhir (20122021), penelitian yang digunakan adalah penelitian kualitatif dengan metode Lieberman Burchard Selain itu, pembuatan review ini dilakukan pencarian data online seperti situs jurnal, google, buku, dan lainlain. Adapun jurnal yang direview sebanyak 5 jurnal penelitian. 
Angel Novia Fransiska, Diba Masyrofah, Hermin Marlian, Irene Virda Sakina dan Putri Setya Tyasna

\section{Hasil dan Pembahasan}

Senyawa golongan terpenoid berpotensi sebagai antifeedant terhadap serangga, bersifat larvasida, dan penolak serangga (repellent). Pengujian senyawa terpenoid dapat diakukan dengan dua cara yaitu dengan metode kualitatif dan kuantitatif, pereaksi Liberman Burchard digunakan untuk identifikasi senyawa golongan terpenoid dengan penampakan warna merah jingga dan steroid dengan warna hijau (Martono \& Setiyono, 2014).

Ditambahkan sedikit anhidrida asetat dengan penguji Liebermann-Burchard yang menyerap air dan dapat membantu pengoksidasn asam oleh asam sulfat, dikarenakan pada reaksi pengoksidasi asam tersebut tidak berlangsung jika masih didalamnya terdapat kandungan air, sedangkan proses pemanasan berguna untuk mempercepat proses penyerapan air oleh anhidrida asetat. Proses terbentuknya warna pada pengujian Lieberman-Burchard yaitu setelah air terserap oleh anhidrida asetatterjadi pengoksidasian asam oleh asam sulfat, kemudian gugus hidrogen beserta elektronnya dilepas, akibatnya senyawa mengalami perpanjangan konjugasi yang memperlihatkan munculnya warna merah \& ungu (Siadi,2012).

1. Identifikasi Senyawa Terpenoid dan Steroid Ekstrak n-Heksan Daun Berwarna Merah dari Syzygium myrtifolium Walp.

Sampel kering daun pucuk merah yang telah dihaluskan sebanyak 1100 gram dimaserasi dengan etanol 96\%. Proses ini dilakukan dengan disaring dan dipekatkan dengan alat rotary evaporator sehingga diperoleh ekstrak totalnya. Ekstrak total difraksinasi dengan etanol dan n-Heksana (Ahda et al., 2016) secara berulang sehingga diperoleh fraksi n-Heksana yang jernih. Kemudian dipekatkan dengan menggunakan rotary evaporator sehingga diperoleh ekstrak n-Heksana (Novianti et al., 2019).

Penelitian yang dilakukan oleh (Novianti et al., 2019) menunjukkan hasil positif dalam skrining fitokimia senyawa triterpenoid dan steroid terhadap ekstrak total etanol dan ekstrak n-heksan daun pucuk merah yang telah diuji dengan pereaksi Liebermann-Burchard.

Tabel 1

Hasil Uji Fitokimia dari Ekstrak Total Etanol dan n-heksan

\begin{tabular}{cccc}
\hline No. & Jenis & \multicolumn{2}{c}{ Jenis Ekstrak } \\
\cline { 2 - 4 } & Senyawa & $\begin{array}{c}\text { Ekstrak Total } \\
\text { Etanol }\end{array}$ & $\begin{array}{c}\text { Ekstrak } \\
\text { N-Heksan }\end{array}$ \\
\hline 1. & Alkaloid & + & + \\
\hline 2. & Saponin & + & - \\
\hline 3. & Steroid & + & + \\
\hline 4. & Triterpenoid & + & + \\
\hline 5. & Flavonoid & + & - \\
\hline 6. & Fenolik & + & - \\
\hline
\end{tabular}

Keterangan :

$(+)=$ mengandung metabolit sekunder

$(-)=$ tidak mengandung metabolit sekunder

Isolasi pada tanaman daun pucuk merah menggunakan kromatografi cair vakum (KCV) dan KK gravitasi. Pada hasil kromatografi cair vakum dengantanaman daun pucuk merah dihasilkan gradien yang diperoleh di KLT dengan fase gerak nheksana:etil asetat (Yulianti, 2020) dan diidentifikasikan dengan sinar UV 254mm \& 366nm, serta pereaksi umumnya $\mathrm{H} 2 \mathrm{SO} 4$ 10\%. Fraksi pada KLT dikelompokkan sesuai dengan gradien fasegeraknya yaitu n-heksan-etil asetat, dan hasil isolasi pada KK gravitasi, fraksi yang dipilih adalah fraksi C dikarenakan jumlahnya relatif banyak. Setelah digunakan KLT kembali dengan fase gerak n-heksana-etil asetat (Suka, 2011) dan didapatkan pula kromatogram dengan nilai HRf 75 \& 55. Dan diidentifikasikan menggunakan pereaksi Lieberman- Buchard yang menunjukkan bahwa 
isolatnya merupakan senyawa golongan terpenoid (Novianti et al., 2019).

2. Identifikasi Senyawa Terpenoid dan Steroid Ekstrak n-Heksan Korteks Batang Salam (Syzygium polyanthum)

Uji steroid dan triterpenoid menggunakan metode LiebermannBuchard, ekstrak dilarutkan dalam kloroform kemudian ditambah pereaksi Liebermann-Buchard (asam asetatanhidrat$\mathrm{H} 2 \mathrm{SO} 4$ ) menunjukkan hasil positif dengan adanya perubahan warna menjadi merah kecoklatan untuk steroid dan coklat-ungu untuk triterpenoid. Reaksi triterpenoid dengan pereaksi Liebermann menghasilkan warna merah-ungu sedangkan steroid memberikan warna hijau-biru. Hal ini didasari oleh kemampuan senyawa triterpenoid dan steroid membentuk warna oleh $\mathrm{H} 2 \mathrm{SO} 4$ dalam pelarut asam asetat anhidrid. Perbedaan warna yang dihasilkan oleh triterpenoid dan streoid disebabkan perbedaan gugus pada atom C-4 (Marliana $\&$ Saleh, 2011).

Tabel 2

Hasil Uji Fitokimia Ekstrak N-Heksan Korteks Batang Salam (Syzygium

\begin{tabular}{ccc}
\multicolumn{3}{c}{ Polyanthum) } \\
\hline No. & Jenis Senyawa & Hasil (+/-) \\
\hline 1. & Flavonoid & - \\
\hline 2. & Alkaloid & - \\
\hline 3. & Fenol & - \\
\hline 4. & Saponin & - \\
\hline 5. & Steroid & + \\
\hline 6. & Terpenoid & + \\
\hline 7. & Triterpenoid & +
\end{tabular}

Keterangan:

$(+)=$ mengandung senyawa metabolit sekunder

$(-)=$ tidak mengandung senyawa metabolit sekunder

3. Identifikasi Senyawa Terpenoid dan Steroid Fraksi n-Heksana Daun Bilaran Tapah (Argyreia nervosa (Burm. F.)

Pada proses ekstrak digunakan metode maserasi yaitu dengan serbuk kasar yang sudah ditimbang sebanyak $1 \mathrm{~kg}$ dan dimasukkan ke dalam maserator. Ekstraksi menggunakan pelarut etanol $96 \%$ hingga $2 \mathrm{~cm}$ diatas permukaan sampel. Proses ekstraksinya dilakukan selama 24 jam dan diaduk setiap 4 jam sekali. Setelah disaring dilakukan remaserasi kembali sebanyak 2 kali dan semua ekstrak cair (filtrat) diuapkan menggunakan rotary evaporator suhu $60^{\circ} \mathrm{C}$ hingga didapatkan ekstrak kental, selanjutnya diuapkan kembali menggunakan waterbath hingga diperoleh ekstrak kental dengan bobot tetap.

Proses ekstrak ini dapat diperoleh dengan cara difraksinasikan menggunakan metode ECC dengan pelarut N-heksan. Setelah menggunakan metode ECC, ekstraknya dilakukan penimbangan sebanyak 15 gram. Kemudian disuspensikan dengan akuades sebanyak 37,5 mL (Mareta, 2020) dan dimasukkan ke dalam corong pisah. Pelarut n-heksana sebanyak $75 \mathrm{~mL}$ ditambahkan ke dalam corong pisah yang sudah berisi suspensi ekstraknya, sehingga membentuk 2lapisan, lapisan atas dan lapisan bawah. Pada senyawa yang larut dalam pelarut $\mathrm{N}$ heksana berada pada lapisan atas. Proses fraksinasi diulangi sebanyak 8 kali dan semua fraksi n-heksana diuapkan menggunakan rotary evaporator dengan suhu $50^{\circ} \mathrm{C}$ hingga didapatkan fraksi kental dan diuapkan menggunakan waterbath sehingga dapat diperoleh bobot tetap sebagai fraksi N-heksan. 
Angel Novia Fransiska, Diba Masyrofah, Hermin Marlian, Irene Virda Sakina dan Putri Setya Tyasna

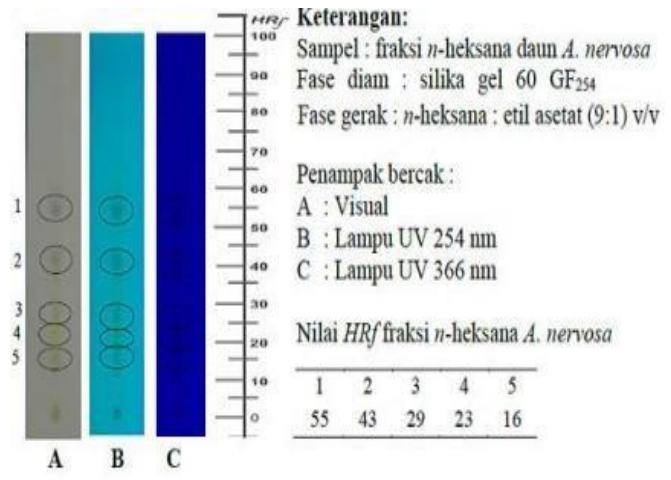

Gambar 1

Kromatogram Fraksi N-Heksana Daun

\section{A. Nervosa}

Selanjutnya dilakukan isolasi dengan Kromatografi Cair Vakum (KCV) dengan cara 3 gram fraksi n-heksanadielusi dengan gradien fase gerak campuran $\mathrm{n}$ heksana-etil asetat (Molyneux, 2004). Masing-masing fraksi menggunakan fase gerak sebanyak $200 \mathrm{~mL}$, sehingga secara berturut-turut didapatkan fraksi A, B, C, D, E, F, G, dan

H. Fraksi hasil KCV diuapkan, selanjutnya dilakukan KLT.

Hasil KCV dari masing-masing gradien diperoleh di KLT dengan fase gerak N-heksan: etil asetat (8:2) v/v dan di identifikasi dengan sinar UV $254 \mathrm{~nm}$ dan UV $366 \mathrm{~nm}$, serta pereaksi umum $\mathrm{H} 2 \mathrm{SO} 4$ $10 \%$.

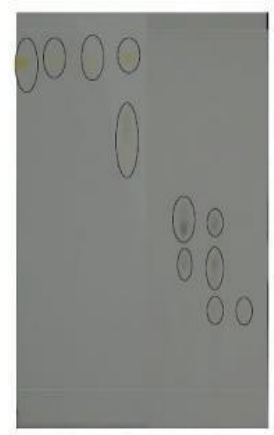

A B C D E F G H

\section{Gambar 2}

Kromatogram Dari Fraksi N-Heksana Daun A. Nervosa Menggunakan KCV C. fraksi C $n$-heksana:etil asetat $(15: 1 \mathrm{~A}) \mathrm{v} / \mathrm{v}$ ; fraksi E $n$-heksana:etil asetat $(9: 1 \mathrm{~B}) \mathrm{v} / \mathrm{v}$ : fraksi $\mathrm{F} n$-heksana:etil asetat $(8: 2 \mathrm{~B}) \mathrm{v} / \mathrm{v}$ $\mathrm{G}$ : fraksi $\mathrm{G} n$-heksana:etil asetat (7:3) v/v : fraksi $\mathrm{H} n$-heksana:etil asetat $(6: 4) \mathrm{v} / \mathrm{v}$ Fase diam silika gel $60 \mathrm{~F}_{254}$ Fase gerak $n$-heksana : etil asetat $(8: 2) \mathrm{v} / \mathrm{v}$ Nilai $H R f$ secara visual \begin{tabular}{cccccccc}
\hline A & B & C & D & E & F & G & H \\
\hline 92 & 92 & 92 & 93 & - & 53 & 53 & 28 \\
& & & 75 & & 46 & 46 &
\end{tabular}

Fraksi yang digunakan untuk KK gravitasi adalah fraksi C dikarenakan jumlah relatifnya sangat banyak. Setelah di KLT kembali dengan fase gerak nheksana-etil asetat (Suka, 2011) didapatkan kromatogram dengan nilai HRf 75 dan 55 seperti disajikan pada Gambar 3A. Isolasi dengan menggunakan $\mathrm{KK}$ gravitasi menggunakan fase gerak $n-$ heksan-etil asetat didapatkan beberapa isolat yang terdiri dari isolat $\mathrm{C}-1, \mathrm{C}-2, \mathrm{C}$ 3, C-4, C5, C-6, dan C-7. Isolat C-4 adalah isolat paling banyak berupa kristal yang berwarna putih membentuk seperti jarum (Gambar 3C) dan identifikasinya menggunakan pereaksi semprot Liebermann-Burchard yang menunjukkan bahwa isolat terdapat senyawa golongan terpenoid.

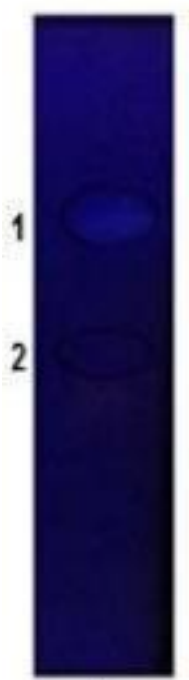

A

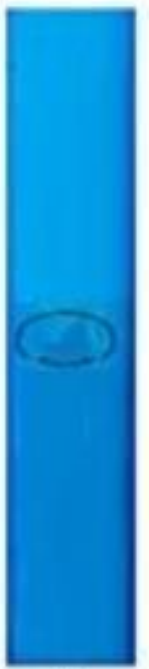

B

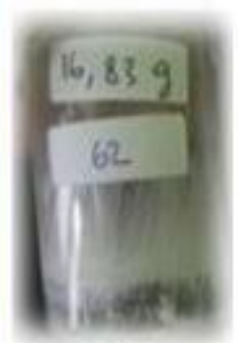

C 
dengan pereaksi $\mathrm{H} 2 \mathrm{SO} 4$ 10\% yang tampak secara visual dan pada lampu UV $254 \mathrm{~nm}$ seperti tersaji pada Gambar 4.

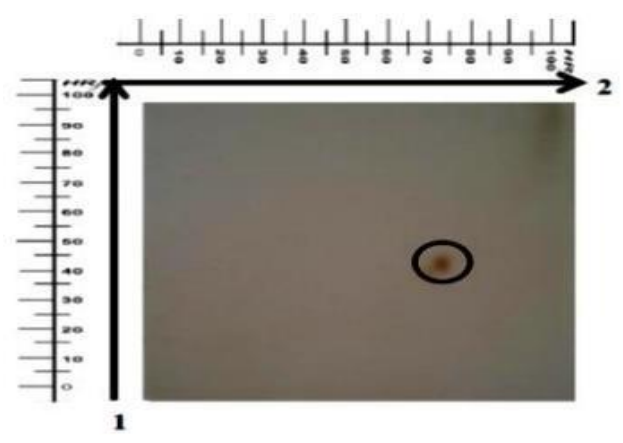

Gambar 4

Kromatogram Dua Dimensi Dari Isolat C4 Hasil KK Gravitasi

4. Identifikasi Senyawa Terpenoid dan Steroid Fraksi n-Heksan Akar Pohon Kayu Buta-buta (Excoecaria agallocha L.)

Ekstraksi yang digunakan pada akar pohon kayu buta-buta adalah metode maserasi. 1,1 kg akar bta-buta direndam menggunakan metanol selama $3 \times 24$ jam maserat disaring dan ditampung lalu dikentalkan dengan rotary evaporator. Ekstrak kental metanol yang dipartisi secara bertahap dengan pelarut $n$-heksana dan etil asetat (Sari et al., 2017).

Tanaman akar pohon kayu buta-buta (E. agallocha) pada fraksinasi ekstrak dibagi menjadi 2 cara yaitu dengan Kromatografi Vakum Cair (KVC) dan Kromatografi Kolom Gravitasi (KKG). Pada KVC, Ekstrak dielusi menggunakan KLT untuk menentukan eluen yang pola pemisahannya paling baik. Fase diam yang digunakan adalah silika gel G60 F254 dan fasa gerak n-heksana: etil asetat; etil asetat 100\%; etil asetat: metanol 100\%. Fraksi tersebut kemudian dipisahkan dengan Kromatografi Vakum Cair (KVC). Masingmasing eluen yang digunakan adalah 100 ml. Fraksi hasil pemisahan ditampung setiap $100 \mathrm{ml}$. Pada KKG,
Sebelum dilakukan kromatografi kolom, dilakukan terlebih dahulu KLT. Tujuannya adalah untuk menentukan senyawa yang positif mengandung terpenoid dengan menggunakan reagen semprot Liebermanbuchard. Selanjutnya fraksi positif terpenoid ini dielusi dengan Kromatografi Kolom Gravitasi dengan eluen bergradien yaitu: n-heksana: etil asetat; etil asetat 100\%; etil asetat: metanol; metanol 100\%. Eluat hasil pemisahan ditampung setiap 5 ml. Eluat dianalisis menggunakan KLT untuk melihat kesamaan pola pemisahan untuk selanjutnya digabungkan (Sari et al., 2017).

Skrining fitokimia senyawa terpenoid dan steroid dilakukan terhadap fraksi ekstrak akar pohon kayu buta-buta seperti penelitian yang dilakukan oleh(Sari et al., 2017) dengan pelarut yang memiliki tingkat kepolaran berbeda sepertin-heksan, etil asetat, dan metanol. Hasil pengujian senyawa terpenoid dan steroid dengan pereaksi lieberman-burchard pada penelitian tersebut menunjukkan bahwa semua fraksi menghasilkan positif mengandung senyawa terpenoid dan steroid. Pada fraksi metanol dan ekstrak kasar akar pohon kayu buta-buta setelah diuji dengan pereaksi lieberman-burchard menunjukkan hasil positif terhadap terpenoid. Hal tersebut dapat dilihat dari terbentuknya warna merah-keunguan. Sedangkan pada fraksi n-heksan dan fraksi etil asetat akar pohon kayu buta-buta menunjukkan hasil positif terhadap steroid yang ditandai dengan terbentuknya warna hijau pada fraksi.

Tabel 3

Hasil Skrining Fitokimia

\begin{tabular}{llcccc}
\hline No. & Metabolit & \multicolumn{5}{c}{ Fraksi } \\
\cline { 3 - 6 } & Sekunder & $\begin{array}{c}\text { Ekstrak } \\
\text { Kasar }\end{array}$ & $\begin{array}{c}\text { N- } \\
\text { Heksan }\end{array}$ & $\begin{array}{c}\text { Etil } \\
\text { Asetat }\end{array}$ & Metanol \\
\hline 1. & Flavonoid & + & - & - & + \\
\hline 2. & Alkaloid & + & + & + & + \\
\hline 3. & Steroid & + & + & + & - \\
\hline 4. & Terpenoid & + & - & - & + \\
\hline 5. & Saponin & - & - & - & - \\
\hline
\end{tabular}


Angel Novia Fransiska, Diba Masyrofah, Hermin Marlian, Irene Virda Sakina dan Putri Setya Tyasna

5. Identifikasi Senyawa Terpenoid dan Steroid Ekstrak n-Heksana Sediaan Losion Daun Jeruk Purut (Citrus hystrix DC)

Tanaman Daun Jeruk Purut Hasil pengujan Liebermann Burchard senyawa terpenoid pada eksrak daun jeruk purut dan sediaan losion ekstrak daun jeruk purut didapatkan hasil bahwa kedua sampel tersebut positif mengandung senyawa terpenoid, tetapi hasil warna yang ditunjukkan sedikit berbeda. Ekstrak daun jeruk purut setelah dilakukan uji didapatkan warna merah tua sedangkan losion daun jeruk purut didapatkan warna merah bata. Perbedaan warna yang didapat diakibatkan karena perbedaan jumlah kandungan terpenoid. Menurut (Widiyati, 2005) bahwa semakin pekat warna hasil pengujian maka semakin banyak kandungan terpenoid. Perubahan warna dari merah tua menjadi merah bata berarti terjadi sedikit pengurangan kandungan terpenoid dari ekstrak daun jeruk purut sampai menjadi sediaan losion. Haltersebut terjadi karena pengaruh penambahan bahan serta dalam proses pembuatan hingga menjadi sediaan losion ekstrak daun jeruk purut.

Tabel 4

Hasil Uji Kualitatif Senyawa Terpenoid Losion Ekstrak Daun Jeruk Purut

\begin{tabular}{lllll}
\hline No. & Sampel & Standar & Hasil & Kesimpulan \\
\hline 1. & $\begin{array}{l}\text { Ekstrak } \\
\text { daun }\end{array}$ & Merah- & Merah & Positif \\
& ungu & Tua & $\begin{array}{l}\text { mengandung } \\
\text { terpenoid }\end{array}$ \\
\hline 2. & Losion & Merah- & Merah & Positif \\
& daun & ungu & bata & mengandung \\
& jeruk & & & terpenoid \\
& purut & & & \\
\hline
\end{tabular}

\section{Kesimpulan}

Berdasarkan hasil penelitian yang telah dilakukan tentang identifikasi senyawa terpenoid dan steroid pada beberapa tanaman menggunakan pelarut n-heksan dapat disimpulkan bahwa pelarut $\mathrm{n}$-heksan mampu menarik senyawa terpenoid dan steroid dengan baik, dimana umumnya senyawa ini bersifat non polar sampai semi polar. Pelarut n-heksan yang bersifat nonpolar akan menarik senyawa nonpolar dan dapat mengekstrak senyawa kimia seperti lilin, lipid dan minyak yang mudah menguap.

\section{BIBLIOGRAFI}

Ahda, M., Fiqrirozi, F., Habibah, G. N., Lestari, M. U., Hardianto, T., \& Andriani, Y. (2016). Optimation Of Ethanol Extract Of Centella Asiatica And Cresintia Cujete Composition As Natural Antioxidant Source. Eksakta: Journal Of Sciences And Data Analysis, 16(1), 9-16. Google Scholar

Anggraeni, D. N. (2016). Uji Aktivitas Antibakteri Ekstrak Daun Katuk (Sauropus Androgynus (L) Merr)Sebagai Alternatif Pembuatan Handsanitizer. Universitas Negeri Semarang. Google Scholar

Habibi, A. I., Firmansyah, R. A., \& Setyawati, S. M. (2018). Skrining Fitokimia Ekstrak N-Heksan Korteks Batang Salam (Syzygium Polyanthum). Indonesian Journal Of ChemicalScience, 7(1), 1-4. Google Scholar

Irawan, T. A. (2010). Peningkatan Mutu Minyak Nilam Dengan Ekstraksi Dan Destilasi Pada Berbagai Komposisi Pelarut. Diponegoro University. Google Scholar

Mareta, C. A. (2020). Efektifitas Pegagan (Centella Asiatica) Sebagai Antioksidan. Jurnal Medika Hutama, 2(01), 390-394. Google Scholar

Marliana, E., \& Saleh, C. (2011). Uji Fitokimia Dan Aktivitas Antibakteri Ekstrak Kasar Etanol. Fraksi N- Heksana, Etil Asetat Dan Metanol Dari Buah Labu Air. Google Scholar

Martono, B., \& Setiyono, R. T. (2014). 
Skrining Fitokimia Enam Genotipe Teh. Google Scholar

Molyneux, P. (2004). The Use Of The Stable Free Radical Diphenylpicrylhydrazyl (Dpph) For Estimating Antioxidant Activity. Songklanakarin J. Sci. Technol, 26(2), 211-219. GoogleScholar

Novianti, T., Juniantito, V., Jusuf, A. A., Arida, E. A., Jusman, S. W. A., \& Sadikin, M. (2019). Prediksi Dna Primer Gen Pgc-1 $\alpha$ Cecak (Hemidactylus Platyurus) Dengan Metoda Phylogenetic, Multiple Alignment, Dan Qpcr. Indonesian Journal of Biotechnology And Biodiversity, 3(1), 39-47. Google Scholar

Sari, D. J., Fadiawati, N., \& Tania, L. (2017). Efektivitas E-Book Interaktif Asam Basa Berbasis Representasi Kimia Dalam Meningkatkan Pemahaman Konsep. Jurnal Pendidikan Dan Pembelajaran Kimia, 7(2), 237-250. Google Scholar

Siadi, K. (2012). Ekstrak Bungkil Biji Jarak Pagar (Jatropha Curcas) Sebagai Biopestisida Yang Efektif Dengan Penambahan Larutan Nacl. Jurnal Mipa,
35(1). Google Scholar

Suka, I. S. R. (2011). Uji Aktivitas Antioksidan Bawang Dayak (Eleutherine Palmifolia (L.) Merr) Dan Bawang Merah (Allium Cepa L.). Skripsi. Program Studi Kimia Jurusan Sekolah Tinggi Mipa Bogor. Google Scholar

Widiyati, R. M. I. (2005). Peningkatan Keterampilan Membaca Pemahaman Dengan Teknik Skrambel Pada Siswa Kelas Iv D Sd Pl Bernardus Semarang Tahun Pelajaran 2004/2005. Universitas Negeri Semarang. Google Scholar

Yulianti, D. (2020). \#\# Common. Prefixandtittle. Tip\#\# Aktivitas Antioksidan Daun Pegagan (Centella Asiatica L. Urban) Dan Bunga Krisan (Crhysanthemum Sp) Pada Tiga Variasi Suhu Pengeringan. Pasundan Food Technology Journal (Pftj), 6(3), 142147. Google Scholar

\section{Copyright holder :}

Angel Novia Fransiska, Diba Masyrofah, Hermin Marlian, Irene Virda Sakina dan Putri Setya (2021)

First publication right :

Jurnal Health Sains

This article is licensed under: 